\title{
Blasts 10 Percent or More of Bone Marrow Nucleated Cells
}

National Cancer Institute

\section{Source}

National Cancer Institute. Blasts 10 Percent or More of Bone Marrow Nucleated Cells. NCI Thesaurus. Code C136648.

A semi-quantitative microscopic finding indicating that at least 10 percent of the nucleated cells in a bone marrow sample are immature mononuclear cells. 